\title{
VECM and Variance Decomposition: An Application to the Consumption-Wealth Ratio
}

\author{
François De Paul Silatchom ${ }^{1}$ \\ ${ }^{1}$ School for Graduate Studies, SUNY-Empire State College, New York, USA \\ Correspondence: François De Paul Silatchom, School for Graduate Studies, SUNY-Empire State College, 325 \\ Hudson Street $3^{\text {rd }}$ Floor, New York, NY 10013, USA. Tel: 1-646-230-1273. E-mail. Francois.Silatchom@esc.edu
}

Received: April 6, 2017

doi:10.5539/ijef.v9n6p188
Accepted: May 19, 2017

Online Published: May 25, 2017

URL: https://doi.org/10.5539/ijef.v9n6p188

\begin{abstract}
This study uses a variance decomposition technique, which doesn't rely on the underlying economic theory, in order to implement a permanent-transitory variance decomposition of the consumption-wealth ratio. We break down the wealth variable into financial assets, tangible assets, and human assets. Using quarterly data over the last six decades, we rely on cointegration analysis as the framework for the study, in order to assess the long-term interrelation between consumption shocks, and those from each of the above mentioned wealth components. Our results indicate that wealth components tend to exhibit permanent shocks, while consumption shocks appear to be transitory. Moreover, the results also indicate a low contemporaneous correlation between shocks in consumption and the ones from financial assets, and also between shocks in consumption and the ones from tangible assets. In addition, the variance decomposition of consumption shocks seems to indicate that, over the time a significantly increasing proportion of consumption shocks is explained by financial assets.
\end{abstract}

Keywords: cointegration, error correction model, variance decomposition, consumption-wealth ratio

\section{Introduction}

In this study, we implement a variance decomposition technique on a system of time-series variables, in order to determine which ones tend to exhibit long term permanent shocks, and which ones tend to have transitory shocks in the long run. One particularity of the technique we use in order to achieve this variance decomposition, is that it doesn't rely on any specific underlying economic theory. Our system of variables derives from the consumption-wealth ratio, from which we break down the wealth variable component into financial assets, tangible assets, and human assets, in order to obtain along with the consumption variable, a system of four time-series variables to work with. The study relies extensively on vector autoregression analysis VAR, and more specifically on error correction models ECM, to achieve the permanent-transitory variance decomposition between the variables in the model. Gonzalo and Granger (1995), suggest a way of using error correction model to implement a permanent-transitory variance decomposition in a system of two variables, and Gonzalo and $\mathrm{Ng}$ (2001), use the error correction model to implement a permanent - transitory decomposition in a multivariate context with a system of three variables, in such a way that the outcome doesn't rely on the underlying economic theory.

The main results of this study appear to indicate that over the past six decades covered by our data, all wealth components exhibit permanent shocks while consumption shocks are transitory. Moreover, the results indicate that there's a low contemporaneous correlation between innovations in consumption and the ones from financial assets, and also between innovations in consumption and the ones from tangible assets. In addition, the variance decomposition of consumption shocks indicates that over the time, a significantly increasing proportion of consumption shocks is explained by financial assets. A fact that seem to suggest that the consumption-wealth linkage apparently manifest itself essentially through financial assets.

The rest of the paper is structured as follows: In the next section (section 2) we present a review of previous studies related to this topic, then in section 3 we present the theoretical framework of our work, and in section 4 we present our empirical framework. The main results, as well as the main implications of our findings are presented in section 5, and finally the conclusion is presented in section 6 . 


\section{Literature History}

Several other studies explore issues related to those considered here. Anthony Garratt, Donald Robertson, and Stephen Wright (2004), suggest a multivariate version of the Beveridge-Nelson Permanent-Transitory decomposition, as a tool to assess what are the economic mechanisms that pull a given variable towards its trend. They show that transitory components can be related directly to the underlying stationary process that drives the system. Campbell and Mankiw (1987); in Permanent-Transitory Components and Economics Fluctuations, fail to reject the hypothesis that fluctuations in real GNP appear to represent only deviations from the deterministic trend. However, they also consider the possibility that this finding might be due to the failure to distinguish the business cycle from other fluctuations in real GNP. Gonzalo and Granger (1995), propose a new way of estimating common long memory components of large cointegrated systems. John Cochrane (1994) in "Permanent and Transitory Components of GNP and Stock Prices", uses a two-variable vector autoregression framework, to characterize transitory components in GNP and stock prices. He finds that shocks to GNP holding consumption constant, are almost entirely transitory, and account for large fractions of the variance of GNP growth. He finds also in the same study that shocks to prices holding dividends constants, are almost entirely transitory. Gonzalo and $\mathrm{Ng}$ (2001), propose a systematic framework for analyzing the dynamic effects of permanent and transitory shocks, on a system of $n$ variables, using a two-step orthogonalization of the residuals of a VECM with $r$ cointegrating vectors. Martin Lettau and Sydney Ludvigson (2003), in "Understanding Trend and Cycle in Asset Values: Reevaluating the Wealth Effect on Consumption", investigate the wealth-consumption linkage, in an attempt to explain why there are movements in asset values that often seem to be disassociated with important movements in consumer spending. They find enough evidence to support that only a small fraction of the variation in household net worth is related to variation in aggregate consumer spending, with the precision, they continue, that this does not mean that wealth has no effect on consumer spending, but rather, that only permanent changes in wealth are associated with movements in consumption. More recently, Francis X. Diebold and Kamil Yilmaz (2011), in "On The Network Topology of Variance Decomposition", combine VAR variance decomposition theory and network topology theory, to provide a way to assess measures of the connectedness among financial asset returns and volatilities.

Our current study, partly follows on these steps of Lettau and Ludvigson (2003), in assessing the wealth-consumption linkage, but by decomposing the wealth element into three components: financial assets, tangible assets, and human assets, while relying on the variance decomposition framework developed by Gonzalo and Granger (1995), and Gonzalo and Ng (2001).

\section{Consumption-Wealth Ratio and Wealth Decomposition.}

The methodology we use in this study is that of a representative agent economy in which all wealth, including human capital, is tradable. The theoretical framework is based on the simple accumulation equation for aggregate wealth, written as:

$$
W_{t+1}=\left(1+R_{w, t+1}\right)\left(W_{t}-C_{t}\right)
$$

Where $R_{w, t+1}$ is the net return on aggregate wealth.

We use an adaptation of the derivations by Campbell and Mankiw (1989), in "Consumption, Income, and Interest Rates: Reinterpreting the Time Series Evidence, in Oliver Blanchard and Stanley Fischer, NBER Macroeconomics Annual: 1989, Cambridge, MA: MIT Press, 1989, pp. 185-216", and also those from Campbell and Shiller (1986), in "Dividend-Price Ratio and Expectations of Future Dividends and Discount Factors", in order to transform the accumulation equation for aggregate wealth (1), into the following expression in which the consumption-wealth ratio is expressed as a function of expected future returns on wealth, and expected future consumption growth (in logarithms):

$$
\left(c_{t}-w_{t}\right)=\mathrm{E}_{t} \sum_{i=1}^{\infty} \rho_{w}{ }^{i}\left(r_{w, t+i}-\Delta c_{t+i}\right)
$$

Where $E_{t}$ is the expectation operator conditional on information available at time $t$.

Now, considering the decomposition of aggregate wealth into financial, tangible, and human assets, as $W_{t}=F_{t}+T_{t}+H_{t}$, where:

$W_{t}=$ Market Value of wealth at time $t$,

$F_{t}, T_{t}$, and $H_{t}$, Market value of financial, tangible and human assets at time $t$, measured as the present value at time $t$, of the stream of expected future returns from $F_{t}, T_{t}$, and $H_{t}$, respectively. The human assets here can consist of the training, the experience, the knowledge, or any combination of these that an individual may poses, and is assumed here to have a marketable value of $H_{t}$ at any time $t$, and is included in the aggregate wealth value 
$W_{t}$.

Since the stock of human wealth is not directly observable, we follow Ludvigson and Lettau (2001), in "Consumption, Aggregate Wealth, and Expected Stock Returns JOF vol.56", by assuming that the non-stationary component of human capital, denoted $H_{t}$, can be well described by aggregate labor income, $Y_{t}$. Campbell (1996), in "Understanding Risk and Return, JPE vol. 104-2", considers labor income as the dividend on human capital.

Considering the breakdown of the aggregate wealth variable, and under the additional assumption that the aggregate wealth returns $R_{w, t+1}$, can be considered as a weighted sum of the returns from each individual wealth components, our log consumption - wealth ratio can be represented as follows:

$$
c_{t}-\alpha_{f} f_{t}-\alpha_{\tau} \tau_{t}-\alpha_{y} y_{t} \approx \mathrm{E}_{t} \sum_{i=1}^{\infty} \rho_{w}{ }^{i}\left\{\left[\omega_{f} \Delta f_{t+i}+\omega_{\tau} \Delta \tau_{t+i}+\left(1-\omega_{f}-\omega_{\tau}\right) \Delta y_{t+i}\right]-\Delta c_{t+i}\right\}
$$

Where the parameters $\alpha_{f}, \alpha_{\tau}$, and $\alpha_{y}$ are theoretically equal to the shares of financial assets, tangible assets, and labor income in the log of aggregate wealth respectively, and $\omega_{f}, \omega_{\tau}$, and $\left(1-\omega_{f}-\omega_{\tau}\right)$ their respective shares in the aggregate wealth return.

Equation (3) is a consumption-based present value relation involving future growth of each component of our wealth decomposition, as well as future consumption growth. This equation suggests that in case $\Delta f_{t}, \Delta \tau_{t}, \Delta y_{t}$, and $\Delta c_{t}$ are covariance stationary, then consumption, financial assets, tangible assets, and labor income, are cointegrated. It also implies that deviations from their common trend, represented by the left-hand-side of (3), provide a rational growth forecast of any one of the four variables in the system, or of some combination of them. The parameters $\alpha_{f}, \alpha_{\tau}$, and $\alpha_{y}$ represent the cointegrating coefficients.

\section{Empirical Framework: Model and Variables Description}

The main empirical approach in this study is the use of cointegration to identify permanent and transitory components between consumption, financial assets, tangible assets, and labor income. We denote by $x_{t}=\left(c_{t}, f_{t}, \tau_{t}, y_{t}\right)^{\prime}$ the vector of dependent variables in the model, representing respectively $\log$ of real consumption expenditures, log of real net financial assets, log of real tangible assets, and log of real labor income respectively.

The Augmented Dickey Fuller test is performed on these four variables. Said and Dickey (1984) demonstrate that the ADF test is asymptotically valid in the presence of a moving average (MA) component, provided that sufficient lagged difference terms are included in the test regression. We choose to run the test with the more general specification that includes both a constant and a linear trend, and without additional exogenous variables. The standard recommendation is to choose a specification that is a plausible description of the data under both the null and alternative hypotheses, (Hamilton 1994, p. 501). In specifying the number of lagged difference terms to be added to the test regression, the usual recommendation is to include a number of lags sufficient to remove serial correlation in the residuals. The unit roots test on each variable in the system suggests that all the variables contained in $x_{t}$ are first order integrated, or I(1).

To obtain a correctly specified error-correction model, we begin by testing for both the presence and number of cointegrating relations in $x_{t}$. Prior for doing that, two important issues needed to be investigated. That's whether to include the trend and/or the drift parameters in the model, and what is the appropriate lag length of the system.

Johansen (1994) suggests that:

One should include a time trend in the VECM if we suspect that:

- The components of the vector $\alpha^{\prime} X_{t}$ (or some combination of them) are trend stationary, so that they veer apart.

- $X_{t}$ is trend stationary rather than a multivariate unit root with drift process. We may want to test this hypothesis under the trend stationarity hypothesis that the matrix $A(1)=\gamma \alpha^{\prime}$ has full rank $(n)$. One of Johansen's cointegration tests, the trace test, has this as alternative hypothesis.

Following these recommendations by Johansen (1994), the plot of all our four variables expressed in logs (Appendix B), suggests that we should not include drift, nor trend in our analysis.

The remaining issue which is the lag length, is dealt with by relying on the minimum value of the Akaike Information Criterion, AIC.

The cointegration test suggest the presence of a single cointegrating vector; which we impose in the VECM 
specifcation from now on. The cointegrating coefficient on consumption is normalized to one, and we denote the single cointegrating vector for $x_{t}=\left(c_{t}, f_{t}, \tau_{t}, y_{t}\right)^{\prime}$, as $\alpha=\left(1,-\alpha_{f},-\alpha_{\tau},-\alpha_{y}\right)^{\prime}$.

We therefore consider from now on, the VECM representation specified below, using lower case for the system vectors of variables:

$$
\Delta x_{t}=\gamma \alpha^{\prime} x_{t-1}+\Gamma(L) \Delta x_{t-1}+e_{t}
$$

$\Delta x_{t}$ is the vector of $\log$ first differences, $\left(\Delta c_{t}, \Delta f_{t}, \Delta \tau_{t}, \Delta y_{t}\right)^{\prime}, \gamma=\left(\gamma_{c}, \gamma_{f}, \gamma_{v}, \gamma_{y}\right)^{\prime}$ is the $(4 \times 1)$ vector of adjustment coefficients. It will be an important factor in telling us which variables subsequently adjust to restore the common trend when a deviation occurs. The Granger Representation Theorem states that, if a vector $x_{t}$ is cointegrated, at least one of the adjustment parameters, $\gamma_{c}, \gamma_{f}, \gamma_{0}$, or $\gamma_{y}$ must be nonzero in the error-correction representation (4). Thus if $x_{j}$ does at least some of the adjusting needed to restore the long-run equilibrium subsequent to a shock that distorts this equilibrium, $\gamma_{j}$ should be different from zero in the equation for $\Delta x_{j}$ of the error-correction representation. $\Gamma(L)$ is a finite order distributed lag operator, and $\alpha=\left(1,-\alpha_{f},-\alpha_{\tau},-\alpha_{y}\right)^{\prime}$ is the $(4 \times 1)$ vector of cointegrating coefficients. Throughout this paper, we use "hats" to denote the estimated values of parameters. The term $\alpha^{\prime} x_{t-1}$ gives last period's equilibrium error, or cointegrating residual.

\section{Main Results and Implications}

Table 1. Minimum information criterion

\begin{tabular}{lcccccc}
\hline Lag & MA 0 & MA 1 & MA2 & MA 3 & MA 4 & MA 5 \\
\hline AR 0 & -11.78861 & -11.63212 & -11.57118 & -11.50699 & -11.4516 & -11.39751 \\
AR 1 & -36.77828 & -36.69077 & -36.65201 & -36.7775 & -36.83518 & -36.87385 \\
AR 2 & -36.99628 & -36.97361 & -36.88726 & -36.88588 & -36.86558 & -36.93982 \\
AR 3 & -36.99651 & -36.9579 & -36.89507 & -36.886 & -36.83848 & -36.84815 \\
AR 4 & $\mathbf{- 3 7 . 0 2 1 8 6}$ & -36.95866 & -36.90829 & -36.80901 & -36.76287 & -36.78745 \\
AR 5 & -36.98839 & -36.96623 & -36.87961 & -36.79413 & -36.812 & -36.75959 \\
\hline
\end{tabular}

The test indicates a number of lag length of 4 periods.

Table 2. Cointegration rank test using trace

\begin{tabular}{ccccccc}
\hline H0: Rank=r & H1: Rank $>$ r & Eigenvalue & 5\% Critical Trace & Drift Value & Drift in in ECM & Process \\
\hline 0 & 0 & 0.1979 & 60.8726 & 39.71 & NOINT & Constant \\
$\mathbf{1}$ & $\mathbf{1}$ & $\mathbf{0 . 0 4 0 6}$ & $\mathbf{1 4 . 1 2 7 4}$ & $\mathbf{2 4 . 0 8}$ & & \\
2 & 2 & 0.0136 & 5.3317 & 12.21 & & \\
3 & 3 & 0.0114 & 2.4329 & 4.14 & & \\
\hline
\end{tabular}

Table 3. Long-run parameter (alpha) estimates when RANK=1

\begin{tabular}{cc}
\hline Variable & \\
\hline consumption & 1.00000 \\
financial assets & 0.01237 \\
tangible assets & -0.62314 \\
labor income & -0.45246 \\
\hline
\end{tabular}

Table 4. Adjustment coefficient (gamma) estimates when RANK=1

\begin{tabular}{cc}
\hline Variable & \\
\hline consumption & -0.00728 \\
financial assets & -0.01383 \\
tangible assets & 0.00040 \\
labor income & 0.00388 \\
\hline
\end{tabular}


The stationarity tests performed on all four variables of the system: $C_{t}, f_{t}, \tau_{t}$, and $y_{t}$, respectively consumption, net financial assets, tangible assets, and labor income, (all variables are in logs) suggest that all four variables are I(1). The cointegration test has been conducted using the cointegrating rank test and an AIC minimum value, with a lag length of 4 periods (Table 1). They suggest the presence of a single cointegrating vector, at a significance level of 5\% (Table 2). The estimates of the cointegrating vector represented in this study by $\alpha$, is then given by $\hat{\alpha}^{\prime}=(1,0.0124,-0.6231,-0.4525)$ with all the coefficients normalized with respect to consumption (Table 3). Also, the estimates of the unrestricted long-run adjustment coefficients, whose vector is represented by $\gamma$ in this study, are given by $\hat{\gamma}^{\prime}=(-0.00728,-0.01383,0.00040,0.00388)$, for consumption, net financial assets, tangible assets, and labor income, respectively (Table 4).

Table 5. Error correction model estimates

\begin{tabular}{|c|c|c|c|c|}
\hline & \multicolumn{4}{|c|}{ Dependent Variables } \\
\hline & $\Delta c_{t}$ & $\Delta f_{t}$ & $\Delta \tau_{t}$ & $\Delta y_{t}$ \\
\hline$c f t y_{t-1}$ & -0.00728 & -0.01383 & 0.00040 & 0.00388 \\
\hline t-Value & $(-5.73)$ & $(-1.46)$ & (0.19) & (1.66) \\
\hline$\Delta c_{t-1}$ & 0.10524 & 0.00788 & 0.05397 & 0.42404 \\
\hline t-Value & (1.40) & $(0.01)$ & $(0.43)$ & (3.10) \\
\hline$\Delta c_{t-2}$ & 0.04163 & 0.26677 & 0.24718 & 0.05106 \\
\hline $\mathrm{t}$-Value & $(0.54)$ & $(0.47)$ & (1.92) & $(0.36)$ \\
\hline$\Delta c_{t-3}$ & 0.05568 & -0.31752 & 0.28290 & 0.34894 \\
\hline t Value & $(0.73)$ & $(-0.56)$ & (2.21) & $(2.51)$ \\
\hline$\Delta f_{t-1}$ & 0.03563 & 0.24421 & 0.31959 & 0.14881 \\
\hline t-Value & $(0.86)$ & $(0.80)$ & (4.59) & (1.97) \\
\hline$\Delta f_{t-2}$ & -0.00616 & -0.13318 & 0.08784 & -0.09865 \\
\hline t-Value & $(-0.15)$ & $(-0.43)$ & (1.24) & $(-1.29)$ \\
\hline$\Delta f_{t-3}$ & 0.05148 & -0.25899 & 0.19258 & 0.09909 \\
\hline t-Value & $(1.26)$ & $(-0.85)$ & (2.80) & $(1.33)$ \\
\hline$\Delta \tau_{t-1}$ & 0.03000 & 0.02724 & 0.02890 & 0.05001 \\
\hline $\mathrm{t}$-Value & (3.21) & $(0.39)$ & (1.84) & (2.93) \\
\hline$\Delta \tau_{t-2}$ & 0.01351 & 0.01344 & 0.02065 & 0.04764 \\
\hline $\mathrm{t}$-Value & (1.42) & $(0.19)$ & (1.29) & (2.73) \\
\hline$\Delta \tau_{t-3}$ & 0.01515 & 0.04952 & 0.00431 & 0.06503 \\
\hline t-Value & (1.58) & (0.69) & $(0.27)$ & (3.70) \\
\hline$\Delta y_{t-1}$ & 0.04350 & -0.10332 & -0.07000 & -0.00097 \\
\hline t-Value & (1.09) & $(-0.35)$ & $(-1.04)$ & $(-0.01)$ \\
\hline$\Delta y_{t-2}$ & -0.00769 & -0.21282 & 0.00504 & 0.04764 \\
\hline t-Value & $(-0.20)$ & $(-0.73)$ & $(0.08)$ & (2.73) \\
\hline$\Delta y_{t-3}$ & -0.01337 & 0.16172 & -0.09533 & -0.14762 \\
\hline $\mathrm{t}$-Value & $(-0.35)$ & $(0.57)$ & $(-1.48)$ & $(-2.11)$ \\
\hline R-squared & 0.1549 & 0.0143 & 0.3167 & 0.3408 \\
\hline $\operatorname{Pr}>F$ & 0.0033 & 0.9997 & $<.0001$ & $<.0001$ \\
\hline
\end{tabular}

Result \#1: From this four-variables cointegrating system, the presence of a single cointegrating equation suggests that there are three permanent components and one transitory component, following Gonzalo and $\mathrm{Ng}$. In order to determine which are the common long-memory components of the system of variables, we follow Gonzalo and Granger (1995), in identifying the common factors. Since the last three adjustment coefficients are not statistically significant (very low t-statistics), Gonzalo and $\mathrm{Ng}$ (2001) recommend to restrict them to zero. When we impose that restriction, our restricted vector of adjustment coefficient estimates becomes, $\hat{\gamma}^{\prime}=(-0.00728,0,0$, 0 ). We use these values to obtain the orthogonal matrix $\hat{\gamma}_{\perp}$, defined such that $\hat{\gamma}_{\perp} \hat{\gamma}=0$. We then implement the permanent-transitory decomposition of the variables in the system. Our decomposition indicates that the common factors, i.e those variables that exhibit a permanent shocks, are financial assets, tangible assets, and 
labor income. Consumption shocks however are transitory. This means, according to Engle and Granger (1987) interpretation, that a deviation from the common trend shared by consumption, financial assets, tangible assets, and labor income, can better be described as transitory movements mostly in consumption. This indicates that consumption is the variable that adjusts itself to push the system back to equilibrium after a temporary move away from it.

The finding that consumption shocks are transitory, and wealth shocks are permanent, seems contrary to those obtained by Lettau and Ludvigson (2003), where, with a different wealth decomposition into assets wealth and non-assets, they found assets' shocks essentially transitory, whereas consumption shocks were mostly permanent. One possible explanation of the difference between the two results, could well be explained by the difference in the lag-length used in the VECM estimation: Our lag-length test suggested a four periods lag, which we have applied in the estimation, while the other uses one period lag. According to Gonzalo and $\mathrm{Ng}$ (2001), the number of lag-length periods included in the estimation, has an important effect on the statistical significance of the adjustment coefficients; And the vector of adjustment coefficients estimates $\hat{\gamma}$ itself, is very important when implementing the permanent-transitory decomposition. As $\mathrm{Ng}$ and Gonzalo (2001) point out, the role of $\gamma$ in any Permanent-Transitory decomposition is very crucial since $\gamma_{\perp}$ defines the permanent shocks.

Our results however, are consistent with the idea that agents are expected to adjust their consumption expenditures to changes in their wealth with a certain time delay which, we can refer to as the delay of consumption adjustment to wealth.

Table 6. Cross correlation of residuals

\begin{tabular}{|c|c|c|c|c|c|}
\hline Lag & Variable & cons & f. assets & t. assets & income \\
\hline \multirow[t]{4}{*}{0} & cons & 1.00000 & 0.15901 & 0.14481 & 0.40638 \\
\hline & f. assets & 0.15901 & 1.00000 & 0.07427 & 0.09272 \\
\hline & t. assets & 0.14481 & 0.07427 & 1.00000 & 0.26512 \\
\hline & income & 0.40638 & 0.09272 & 0.26512 & 1.00000 \\
\hline \multirow[t]{4}{*}{1} & cons & -0.00218 & 0.00759 & -0.01546 & -0.01510 \\
\hline & f. assets & -0.01479 & -0.01249 & 0.00353 & -0.01339 \\
\hline & t. assets & 0.02537 & 0.03110 & -0.02087 & 0.00781 \\
\hline & income & -0.01378 & 0.00461 & -0.04739 & -0.04319 \\
\hline \multirow[t]{4}{*}{2} & cons & 0.00348 & 0.01026 & 0.00531 & -0.02468 \\
\hline & f. assets & -0.00818 & -0.00558 & -0.00363 & -0.00698 \\
\hline & t. assets & 0.02665 & 0.02665 & 0.01184 & -0.01523 \\
\hline & income & -0.00097 & 0.01615 & 0.03983 & -0.08706 \\
\hline \multirow[t]{4}{*}{3} & cons & 0.00968 & 0.00035 & 0.00848 & -0.04104 \\
\hline & f. assets & -0.00604 & 0.00561 & -0.00969 & -0.02101 \\
\hline & t. assets & 0.06782 & 0.03105 & 0.02225 & 0.05197 \\
\hline & income & 0.02765 & -0.00684 & 0.04418 & -0.02218 \\
\hline \multirow[t]{4}{*}{4} & cons & 0.00256 & -0.00918 & 0.07954 & 0.08651 \\
\hline & f. assets & 0.11887 & 0.05410 & 0.06566 & 0.15697 \\
\hline & t. assets & -0.03591 & -0.07988 & 0.06511 & -0.03898 \\
\hline & income & 0.06703 & 0.03993 & -0.02447 & 0.08475 \\
\hline
\end{tabular}

Result \#2: From the table 6, we can also see that there's a low contemporaneous correlation between innovations in consumption and innovations in financial assets, 15.9\%; also, a low contemporaneous correlation between innovations in consumption and innovations in tangible assets, $14.48 \%$. This finding is consistent with Lettau and Ludvigson's finding that, only a small fraction of the variation in wealth is related to variation in consumption. However according to the generated Cholesky variance decomposition for consumption growth residuals (Appendix A, Tables A1, and A2), this statement appears to be true only in a very short horizon. Table A1 appears to indicate that consumption's variance is mostly explained by itself in a very short horizon, and over the time, a significantly increasing proportion of consumption shock is explained by financial assets. The proportions of consumption shocks explained by tangible assets and labor income are relatively insignificant, both at short and long horizon time periods. When the restrictions are imposed on the adjustment coefficients (table A2), the proportion of the consumption shocks explained by financial assets becomes even larger, and the one explained by tangible assets and labor income becomes much smaller, compared to the results obtained without restriction on the adjustment coefficients. 
These ECM estimates of the R-square are respectively, 0.1549 for consumption, 0.0143 for financial assets, 0.3167 for tangible assets, and 0.3408 for labor income (table 5). Their values seem to indicate that, tangible assets growth and labor income growth show strong reliance on the past, consumption growth shows a weak reliance on the history, while financial assets' growth does not seem to rely on its past. In other words, it is not possible to rely on past information to predict financial assets growth, this finding is somehow consistent with the idea behind the efficient market hypothesis.

Table 7. Long-horizon growth of financial assets, tangible assets, labor income, and consumption, on cfty

\begin{tabular}{|c|c|c|c|c|c|c|c|c|c|}
\hline \multirow[t]{2}{*}{ Horizon } & \multirow[t]{2}{*}{ Variables } & \multicolumn{2}{|c|}{ Panel A } & \multicolumn{2}{|c|}{ Panel B } & \multicolumn{2}{|c|}{ Panel C } & \multicolumn{2}{|c|}{ Panel D } \\
\hline & & $\sum \Delta f_{t+h}$ & $R^{2}$ & $\Sigma \Delta \tau_{t+h}$ & $R^{2}$ & $\Sigma \Delta y_{t+h}$ & $R^{2}$ & $\Sigma \Delta c_{t+h}$ & $R^{2}$ \\
\hline \multirow{6}{*}{1} & intercept & 0.06759 & & -0.02771 & & 0.03255 & & 0.01693 & \\
\hline & & {$[1.56]$} & & {$[-2.34]$} & & {$[2.46]$} & & [2.65] & \\
\hline & $c f z y_{t}$ & & 0.0087 & & 0.0463 & & 0.0164 & & 0.0074 \\
\hline & & 0.07844 & & -0.05022 & & 0.03296 & & 0.01063 & \\
\hline & & [1.37] & & {$[-3.22]$} & & [1.89] & & [1.26] & \\
\hline & intercept & 0.12947 & & -0.06840 & & 0.05596 & & 0.03026 & \\
\hline \multirow[t]{5}{*}{2} & & [2.06] & & {$[-3.48]$} & & [2.64] & & [3.01] & \\
\hline & $c f \tau y_{t}$ & & 0.0151 & & 0.0885 & & 0.0170 & & 0.0072 \\
\hline & & 0.14927 & & -0.11739 & & 0.05376 & & 0.01648 & \\
\hline & & {$[1.80]$} & & {$[-4.54]$} & & [1.92] & & [1.24] & \\
\hline & intercept & 0.17928 & & -0.11499 & & 0.07004 & & 0.04108 & \\
\hline \multirow[t]{5}{*}{3} & & {$[2.28]$} & & [-4.29] & & {$[2.43]$} & & [3.10] & \\
\hline & $c f \tau y_{t}$ & & 0.0181 & & 0.1232 & & 0.0123 & & 0.0055 \\
\hline & & 0.20407 & & -0.19228 & & 0.06220 & & 0.01898 & \\
\hline & & [1.97] & & {$[-5.45]$} & & [1.64] & & [1.09] & \\
\hline & intercept & 0.21055 & & -0.16930 & & 0.08164 & & 0.04550 & \\
\hline \multirow[t]{5}{*}{4} & & [2.27] & & {$[-5.08]$} & & {$[2.31]$} & & [2.81] & \\
\hline & $c f \tau y_{t}$ & & 0.0172 & & 0.1595 & & 0.0096 & & 0.0018 \\
\hline & & 0.23419 & & -0.27707 & & 0.06722 & & 0.01311 & \\
\hline & & [1.92] & & {$[-6.31]$} & & [1.44] & & {$[0.61]$} & \\
\hline & intercept & 0.21938 & & -0.22861 & & 0.08990 & & 0.04807 & \\
\hline \multirow[t]{5}{*}{5} & & {$[2.07]$} & & [-5.87] & & [2.17] & & [2.57] & \\
\hline & $c f \tau y_{t}$ & & 0.0133 & & 0.1981 & & 0.0072 & & 0.0002 \\
\hline & & 0.23450 & & $-\mathbf{0 . 3 6 8 2 7}$ & & 0.06779 & & 0.00475 & \\
\hline & & [1.68] & & {$[-7.18]$} & & {$[1.24]$} & & {$[0.19]$} & \\
\hline & intercept & 0.23131 & & -0.28834 & & 0.10852 & & 0.04688 & \\
\hline \multirow[t]{4}{*}{6} & & {$[1.98]$} & & [-6.59] & & [2.35] & & [2.26] & \\
\hline & $c f \tau y_{t}$ & & 0.0115 & & 0.2347 & & 0.0084 & & 0.0004 \\
\hline & & $\begin{array}{c}0.23905 \\
{[1.56]}\end{array}$ & & $\begin{array}{c}-\mathbf{- 0 . 4 5 9 8 9} \\
{[-7.99]}\end{array}$ & & $\begin{array}{c}0.08200 \\
{[1.35]}\end{array}$ & & $\begin{array}{c}-0.00846 \\
{[-0.31]}\end{array}$ & \\
\hline & intercept & 0.23158 & & -0.34317 & & 0.13040 & & 0.04810 & \\
\hline \multirow[t]{4}{*}{7} & & [1.82] & & {$[-7.18]$} & & [2.56] & & [2.13] & \\
\hline & $c f \tau y_{t}$ & & 0.0089 & & 0.2660 & & 0.0103 & & 0.0018 \\
\hline & & $\begin{array}{c}0.22804 \\
{[1.36]}\end{array}$ & & $\begin{array}{c}-0.54480 \\
{[-8.66]}\end{array}$ & & $\begin{array}{r}0.10041 \\
{[1.49]}\end{array}$ & & $\begin{array}{c}-0.01852 \\
{[-0.62]}\end{array}$ & \\
\hline & intercept & $\begin{array}{c}0.22934 \\
{[1.68]}\end{array}$ & & $\begin{array}{c}-0.39701 \\
{[-7.72]}\end{array}$ & & $\begin{array}{c}0.15775 \\
{[2.84]}\end{array}$ & & $\begin{array}{c}0.05078 \\
{[2.10]}\end{array}$ & \\
\hline \multirow{2}{*}{8} & $c f \tau y_{t}$ & & 0.0069 & & 0.2954 & & 0.0136 & & 0.0033 \\
\hline & & $\begin{array}{c}0.21371 \\
{[1.19]}\end{array}$ & & $\begin{array}{c}-0.62838 \\
{[-9.29]}\end{array}$ & & $\begin{array}{c}0.12583 \\
{[1.72]}\end{array}$ & & $\begin{array}{c}-0.02672 \\
{[-0.84]}\end{array}$ & \\
\hline \multirow[t]{3}{*}{12} & intercept & $\begin{array}{c}0.34286 \\
{[2.00]}\end{array}$ & & $\begin{array}{c}-0.63520 \\
{[-10.33]}\end{array}$ & & $\begin{array}{c}0.20242 \\
{[2.88]}\end{array}$ & & $\begin{array}{c}0.06112 \\
{[2.02]}\end{array}$ & \\
\hline & $c f \tau y_{t}$ & & 0.0099 & & 0.4272 & & 0.0115 & & 0.0105 \\
\hline & & $\begin{array}{c}0.31975 \\
{[1.42]}\end{array}$ & & $\begin{array}{c}-0.99130 \\
{[-12.27]}\end{array}$ & & $\begin{array}{c}0.14461 \\
{[1.56]}\end{array}$ & & $\begin{array}{c}-0.05949 \\
{[-1.50]}\end{array}$ & \\
\hline
\end{tabular}




\begin{tabular}{|c|c|c|c|c|c|c|c|c|c|}
\hline & intercept & 0.82346 & & -0.91400 & & 0.26217 & & 0.07289 & \\
\hline \multirow[t]{4}{*}{20} & & [3.85] & & {$[-13.56]$} & & {$[2.88]$} & & [1.95] & \\
\hline & $c f \tau y_{t}$ & & 0.0465 & & 0.5829 & & 0.0069 & & 0.0371 \\
\hline & & 0.86118 & & -1.45438 & & 0.14108 & & $-\mathbf{0 . 1 3 6 9 7}$ & \\
\hline & & [3.07] & & {$[-16.46]$} & & {$[1.18]$} & & {$[-2.79]$} & \\
\hline
\end{tabular}

$\Sigma \Delta x_{t+h}=\beta_{0}+\beta_{1} c f c y_{t}+\varepsilon_{t+h}$, with $\Sigma \Delta x_{t+h}=\Delta x_{t+1}+\Delta x_{t+2}+\ldots+\Delta x_{t+h}$

Result \#3: In order to assess the predictive content of the consumption-wealth ratio for future consumption growth, the growth of future financial assets, future tangible assets' growth, and future labor income growth, we estimate long-horizons simple regressions of consumption growth, $\Sigma \Delta c_{t+h}$, financial assets growth $\Sigma \Delta f_{t+h}$, tangible asset growth $\Sigma \Delta \tau_{t+h}$, and labor income growth $\Sigma \Delta y_{t+h}$, against the cointegrating residuals $c f \tau y_{t}$ respectively. For this purpose, we make use the following specification: $\Sigma \Delta x_{t+h}=\beta_{0}+\beta_{1} c f \tau y_{t}+\varepsilon_{t+h}$, where $\Sigma \Delta x_{t+h}=\Delta x_{t+1}+\Delta x_{t+2}+\ldots+\Delta x_{t+h}$

Since all the variables were shown to be $\mathrm{I}(1)$, both our dependent and independent variables (expressed in differences) are stationary. Hence, we can rely on the regular t-statistic to assess the statistical significance of the regression coefficients.

The regression results presented in Tables 2 appear to indicate that: On one hand, there's no significant relation between future consumption growth and the consumption-wealth ratio at short horizons. However, at long-horizons the relation appears to be significant (Table 7, Panel D). These results appear to suggest first, that the consumption-wealth ratio significantly predict the future consumption growth only at a long horizon. Second, such an outcome would itself, be consistent with the finding mentioned earlier in Result \#1, that when the system is out of its equilibrium path in short horizon, consumption is the variable that will adjust gradually to allow the whole system to converge back to its long-horizon common trend.

On the other hand, we can observe from Table 7 Panel B, that there's a significant negative relation between future tangible assets' growth and the consumption-wealth ratio over the entire horizon considered. This seems to indicate that: First, the consumption-wealth ratio does significantly predict the growth of future tangible assets. Second, the negative relation between the consumption-wealth ratio and the growth of future tangible assets indicates that a high consumption-wealth ratio today can be related to a low tangible asset growth in the future, and vice-versa. Secondly, this also means, if we consider our data set and, as far the US economy is concerned, that the excess of saving implied by the delay of consumption adjustments to changes in wealth, has significantly and persistently explained the growth of future tangible assets over the entire horizon considered in this study, with a much stronger effect as the time horizon gets longer.

However, there appears to be some weak and unstable relation between future financial asset growth and the consumption-wealth ratio (Table 7 Panel A), and no significant relation between future labor income growth and the consumption-wealth ratio over the entire horizon considered (Table 7 Panel C).

\section{Conclusion}

In this study, we investigate some aspects of the relationship between wealth components and consumption. More specifically we decompose wealth into financial assets, tangible assets, and human assets, and, along with consumption, we first try to identify which variables exhibit permanent shocks and which ones exhibit transitory shocks. In order to achieve this, we use the model derived by Campbell and Mankiw (1988) and, apply our wealth decomposition to obtain a rational expectation intertemporal linear expression, relating the current consumption-wealth ratio to expected future consumption growth, expected future financial assets growth, expected tangible assets growth, and expected human asset's growth. Second, we rely on some of the results obtained from the above investigation, to try to assess the cross correlations, as well as the predictability of each of these variables by the consumption-wealth ratio. We make the assumption that the value of each wealth component reflects the sum of the present values of the stream of revenues expected from these assets. The human asset's value is proxied by labor income.

Our main results in this study indicate that all wealth components exhibit permanent shocks, while consumption shocks are transitory. They also indicate that there's a low contemporaneous correlation between innovations in consumption and financial assets, and also between innovations in consumption and tangible assets. However, a 
variance decomposition of consumption shocks indicates that, over the time a significantly increasing proportion of consumption shocks is explained by financial assets. This particular aspect of our findings seems to suggest that the consumption-wealth linkage in this study manifests itself essentially through financial assets. Finally, we find that the consumption-wealth ratio persistently and significantly predicts future tangible assets growth. This last result appears to indicate that over the entire time horizon considered in this study, the excess of savings resulting from the delay of consumption adjustment to changes in wealth, has most likely and consistently, been converted into tangible assets.

\section{References}

Alvarez, F., \& Urban, J. (2001). The Size of The Permanent Component of the Asset Pricing Kernels. NBER, w8360. https://doi.org/10.3386/w8360

Ang, A., \& Geert, B. (2005). Stock Return Predictability: Is it There? NBER, September.

Bekaert, G., Eric, E., \& Steven, G. (2006). Socks and Bonds Returns with Moody Investors. NBER, w12247.

Bekaert, G., Eric, E., \& Yuhang, X. (2006). Risk, Uncertainty and Asset Prices. NBER, w12248. https://doi.org/10.3386/w12248

Bernanke, B., \& Mark, G. (2000). Monetary Policy and Asset Price Volatility. NBER, w7559. https://doi.org/10.3386/w7559

Blanchard, O. J., \& Danny, Q. (1988). The Dynamic Effects of Aggregate Demand and Supply Disturbances. NBER, w2737. https://doi.org/10.3386/w2737

Boudoukh, J., Matthew, R., \& Robert, F. W. (1994). Inductry Returns and the Fisher Effect. Journal of Finance, 49(5). https://doi.org/10.1111/j.1540-6261.1994.tb04774.x

Campbell, J. Y. (1988). Asset Prices, Consumption, and the Business Cycle. NBER, w6485 March.

Campbell, J. Y. (1990). A Variance Decomposition for Stock Returns. NBER wp3246. https://doi.org/10.3386/w3246

Campbell, J. Y. (1991). A Variance Decomposition for Stock Returns. Econometric Journal, 101(405). https://doi.org/10.2307/2233809

Campbell, J. Y. (1996). Understanding Risk and Return. Journal of Political Economy, 104(2). https://doi.org/10.1086/262026

Campbell, J. Y. (2000). Comment on Low Inflation: The Behavior of Financial Markets and Institutions. Journal of Money, Credit and Banking, 32(4), 1088-1092. https://doi.org/10.2307/2601161

Campbell, J. Y., \& Gregory, N. M. (1987). Permanent and Transitory Components in Macroeconomic Fluctuations. NBER, w2169. https://doi.org/10.3386/w2169

Campbell, J. Y., \& Gregory, N. M. (1989). Consumption, Income, and Interest Rates: Reinterpreting the Time Series Evidence. NBER, w2924. https://doi.org/10.1086/654107

Campbell, J. Y., \& John, A. (1993). What Moves the Stock and Bond Markets? A Variance Decomposition for $\begin{array}{lllll}\text { Long-Term Assets Returns. Journal of } & \text { Finance, }\end{array}$ https://doi.org/10.1111/j.1540-6261.1993.tb04700.x

Campbell, J. Y., \& Pierre, P. (1991). Pitfalls and Opportunities: What Macroeconomists should know about unit roots. NBER tw0100. https://doi.org/10.3386/t0100

Campbell, J. Y., \& Robert, J. S. (1988). Interpreting Cointegrating Models. NBER, w2568, April.

Cochrane, J. (2005). Financial Markets and the Real Economy. Graduate School of Business, University of Chicago, September. https://doi.org/10.3386/w11193

Cochrane, J. H. (1994). Permanent and Transitory Components of GNP and Stock Prices. The Quarterly Journal of Economics, 109(1), 241-265. https://doi.org/10.2307/2118434

Cochrane, J. H. (2001). Asset Pricing. Princeton University Press.

Collard, F., Patrick, F., \& Imen, G. (2006). Predictability and Habit Persistence. JEDC, 30. https://doi.org/10.1016/j.jedc.2005.06.016

Diebold, F. X., \& Yilmaz, K. (2011). On The Network Topology of Variance Decompositions: Measuring The Connectedness Of Financial Firms. NBER, w17490. https://doi.org/10.3386/w17490 
Engle, R. F., \& Byung, S. Y. (1987). Forecasting and Testing Cointegrating Systems. Journal of Econometrics, 35, 143-159. https://doi.org/10.1016/0304-4076(87)90085-6

Engle, R., \& Joao, V. I. (1993). Estimating Sectoral Cycles Using Cointegration and Common Features. NBER, w4529. https://doi.org/10.3386/w4529

Garratt, A., Donald, R., \& Stephen, W. (2004). Permanent vs Transitory Components and Economic Fundamentals. Birkbeck Working Papers in Economics and Finance, University of London.

Gonzalo, J., \& Clive, G. (1995). Estimation of Common Long-Memory Components in Cointegrated Systems. $\begin{array}{lllll}\text { Journal of Business and Economic } & \text { Statistics, } & 13(1), & \text { 27-35. }\end{array}$ https://doi.org/10.1080/07350015.1995.10524576

Gonzalo, J., \& Serena, Ng. (2001). A systematic framework for analyzing the dynamic effects of permanent and transitory shocks. Journal of Economic Dynamics and Control, 25. https://doi.org/10.1016/S0165-1889(99)00062-7

Granger, C., \& Engle. (1987). Cointegration and Error Correction: Representation, Estimation, and Testing. Econometrica, 55.

Jagannathan, R., \& Zhenyu, W. (1996). Conditional CAPM and the Cross-Section of Expected Returns. Journal of Finance, 51(1). https://doi.org/10.1111/j.1540-6261.1996.tb05201.x

Johansen, S. (1994). The Role of the Constant and Linear Terms in Cointegration Analysis of Nonstationary Variables. Econometric Reviews, 13, 205-229. https://doi.org/10.1080/07474939408800284

King, R., Charles, P., James, S., \& Mark, W. (1991). Stochastic Trends and Economic Fluctuations. AER, 81(4).

Lettau, M., \& Sydney, C. L. (2003a). Expected Returns and Expected Dividend Growth. NBER, w9605.

Lettau, M., \& Sydney, C. L. (2003b). Understanding Trend and Cycle in Asset Values: Reevaluating the Wealth Effect on Consumption. NBER, w9848.

Lettau, M., \& Sydney, L. (2001).Consumption, Aggregate Wealth, and Expected Stock Returns. Journal of Finance, 56. https://doi.org/10.1111/0022-1082.00347

Marshall, D. A., \& Nayan, G. P. (1999). Can Costs of Consumption Adjustment Explain Asset Pricing Puzzles? The Journal of Finance, 54(2), 623-654. https://doi.org/10.1111/0022-1082.00119

Quah, D. (1991). The Relative Importance of Permanent and Transitory Components: Identification and Some Theoretical Bounds. NBER, tw0106. https://doi.org/10.3386/t0106

Stock, J. H., \& Mark, W. W. (2003). Forecasting Output and Inflation: The Role of Asset Prices. Journal of Economic Literature, 41(3), 788-829. https://doi.org/10.1257/jel.41.3.788

Stock, J. H., \& Mark, W. W. (2006). Why Has US Inflation Become Harder to Forecast? NBER, w12324, June.

Stock, J., \& Watson, M. (1993). A Simple Estimation of Cointegrating Vectors in Higher Order Integrated Systems. Econometrica, 61(4). https://doi.org/10.2307/2951763

Vahid, F., \& Engle, R. F. (1993). Common Trends and Common Cycles. Journal of Applied Econometrics, 8(4), Oct-Dec.

\section{Appendix}

\section{Data Description}

All the variable series are quarterly data covering the period from 1951-Q1 through 2015-Q3, and are described as follows:

\section{Consumption}

Consumption is measured as expenditure on non-durables and services. The quarterly data are seasonally adjusted at annual rates, in billions dollars. Real consumption data are obtained by deflating consumption data by the GDP deflator, with 2009 the base year. The source is the U.S. Department of Commerce, Bureau of Economic Analysis.

\section{Labor Income}

Labor income data are represented in this study by wage and salary disbursements, and are deflated by the GDP deflator, with 2009 the base year. The quarterly data are seasonally adjusted, in current dollars. The source is the 
Bureau of Economic Analysis.

The other wealth variables

-Total wealth is household net worth in billions of current dollars, measured at the end of the period, not seasonally adjusted.

- Tangible Assets are measured in this study as Real estate + Equipments and software + Consumer durable goods.

- Financial Assets are made of total financial assets from households and non-profit organizations, in billions of dollars, and non-seasonally adjusted.

All these other wealth variables are deflated in this study, by the GDP deflator in order to have their values in real terms. The source for these data is the Board of Governors of the Federal Reserve System. A complete description of these data may be found at http://www.federalreserve.gov/releases/Z1/Current/

\section{Appendix A}

Variance Decomposition of consumption shocks (the transitory shocks), over a 30 (quarters) periods horizon

Table A1

\begin{tabular}{|c|c|c|c|c|c|}
\hline Period & S.E. & $\mathrm{C}$ & FA & TA & $\mathrm{Y}$ \\
\hline 1 & 0.004512 & 100.0000 & 0.000000 & 0.000000 & 0.000000 \\
\hline 2 & 0.007039 & 97.49167 & 1.844834 & 0.509162 & 0.154329 \\
\hline 3 & 0.009213 & 94.70941 & 4.176935 & 1.012008 & 0.101643 \\
\hline 4 & 0.011388 & 90.65578 & 7.179819 & 2.097801 & 0.066604 \\
\hline 5 & 0.013484 & 85.50411 & 11.73058 & 2.713336 & 0.051965 \\
\hline 6 & 0.015437 & 81.79405 & 15.01648 & 3.147360 & 0.042105 \\
\hline 7 & 0.017245 & 79.06731 & 17.37070 & 3.527853 & 0.034135 \\
\hline 8 & 0.018916 & 76.81313 & 19.36574 & 3.792643 & 0.028488 \\
\hline 9 & 0.020460 & 75.05660 & 20.94725 & 3.970185 & 0.025957 \\
\hline 10 & 0.021901 & 73.66154 & 22.17704 & 4.136156 & 0.025260 \\
\hline 11 & 0.023251 & 72.49765 & 23.17743 & 4.298538 & 0.026383 \\
\hline 12 & 0.024530 & 71.50181 & 24.00775 & 4.461275 & 0.029166 \\
\hline 13 & 0.025755 & 70.62963 & 24.70254 & 4.633975 & 0.033861 \\
\hline 14 & 0.026937 & 69.84271 & 25.29502 & 4.822981 & 0.039291 \\
\hline 15 & 0.028086 & 69.11665 & 25.80806 & 5.030060 & 0.045226 \\
\hline 16 & 0.029210 & 68.43211 & 26.25993 & 5.256710 & 0.051246 \\
\hline 17 & 0.030313 & 67.77677 & 26.66316 & 5.502818 & 0.057251 \\
\hline 18 & 0.031400 & 67.14301 & 27.02546 & 5.768608 & 0.062926 \\
\hline 19 & 0.032473 & 66.52507 & 27.35339 & 6.053321 & 0.068219 \\
\hline 20 & 0.033536 & 65.91888 & 27.65213 & 6.355929 & 0.073053 \\
\hline 21 & 0.034589 & 65.32221 & 27.92503 & 6.675310 & 0.077450 \\
\hline 22 & 0.035635 & 64.73334 & 28.17472 & 7.010548 & 0.081388 \\
\hline 23 & 0.036675 & 64.15102 & 28.40355 & 7.360524 & 0.084903 \\
\hline 24 & 0.037709 & 63.57436 & 28.61341 & 7.724214 & 0.088015 \\
\hline 25 & 0.038740 & 63.00274 & 28.80585 & 8.100642 & 0.090763 \\
\hline 26 & 0.039767 & 62.43566 & 28.98227 & 8.488908 & 0.093169 \\
\hline 27 & 0.040792 & 61.87272 & 29.14389 & 8.888123 & 0.095264 \\
\hline 28 & 0.041815 & 61.31364 & 29.29183 & 9.297457 & 0.097075 \\
\hline 29 & 0.042837 & 60.75820 & 29.42705 & 9.716117 & 0.098626 \\
\hline 30 & 0.043859 & 60.20626 & 29.55045 & 10.14335 & 0.099939 \\
\hline
\end{tabular}

Note. Cholesky Ordering: Consumption, Fin. Assets, Tan. Assets, Labor income. 
Table A2

\begin{tabular}{|c|c|c|c|c|c|}
\hline Period & S.E. & $\mathrm{C}$ & FA & TA & $\mathrm{Y}$ \\
\hline 1 & 0.004491 & 100.0000 & 0.000000 & 0.000000 & 0.000000 \\
\hline 2 & 0.006986 & 97.36353 & 1.987846 & 0.516301 & 0.132320 \\
\hline 3 & 0.009127 & 94.32370 & 4.571205 & 1.023987 & 0.081103 \\
\hline 4 & 0.011274 & 89.92244 & 7.914164 & 2.106371 & 0.057026 \\
\hline 5 & 0.013352 & 84.32064 & 12.93961 & 2.698294 & 0.041453 \\
\hline 6 & 0.015289 & 80.32090 & 16.56864 & 3.076910 & 0.033548 \\
\hline 7 & 0.017088 & 77.40388 & 19.18546 & 3.379109 & 0.031552 \\
\hline 8 & 0.018756 & 75.00008 & 21.41931 & 3.549925 & 0.030678 \\
\hline 9 & 0.020304 & 73.11799 & 23.23106 & 3.623954 & 0.026991 \\
\hline 10 & 0.021754 & 71.59974 & 24.70318 & 3.673529 & 0.023544 \\
\hline 11 & 0.023119 & 70.30953 & 25.96240 & 3.706911 & 0.021159 \\
\hline 12 & 0.024418 & 69.18617 & 27.06507 & 3.728146 & 0.020619 \\
\hline 13 & 0.025668 & 68.18540 & 28.04627 & 3.745536 & 0.022792 \\
\hline 14 & 0.026880 & 67.27053 & 28.93822 & 3.763899 & 0.027343 \\
\hline 15 & 0.028060 & 66.41883 & 29.76219 & 3.784719 & 0.034264 \\
\hline 16 & 0.029217 & 65.61228 & 30.53534 & 3.809109 & 0.043271 \\
\hline 17 & 0.030354 & 64.83989 & 31.26871 & 3.837139 & 0.054267 \\
\hline 18 & 0.031476 & 64.09542 & 31.96856 & 3.869157 & 0.066865 \\
\hline 19 & 0.032584 & 63.37394 & 32.64025 & 3.904894 & 0.080920 \\
\hline 20 & 0.033680 & 62.67192 & 33.28791 & 3.943936 & 0.096239 \\
\hline 21 & 0.034767 & 61.98746 & 33.91391 & 3.985887 & 0.112741 \\
\hline 22 & 0.035844 & 61.31906 & 34.52016 & 4.030495 & 0.130277 \\
\hline 23 & 0.036914 & 60.66543 & 35.10838 & 4.077404 & 0.148786 \\
\hline 24 & 0.037977 & 60.02559 & 35.67989 & 4.126328 & 0.168186 \\
\hline 25 & 0.039034 & 59.39874 & 36.23582 & 4.177013 & 0.188427 \\
\hline 26 & 0.040085 & 58.78415 & 36.77716 & 4.229252 & 0.209437 \\
\hline 27 & 0.041132 & 58.18119 & 37.30480 & 4.282838 & 0.231171 \\
\hline 28 & 0.042175 & 57.58930 & 37.81953 & 4.337599 & 0.253572 \\
\hline 29 & 0.043215 & 57.00798 & 38.32206 & 4.393373 & 0.276595 \\
\hline 30 & 0.044251 & 56.43679 & 38.81300 & 4.450019 & 0.300192 \\
\hline
\end{tabular}

Note. Cholesky Ordering: Consumption, Fin. Assets, Tan. Assets, Labor Income.

One can notice that from both tables there's a gradual increase along with the horizon, of the proportion of the consumption variance explained by financial assets, whereas the proportion explained by tangible assets and labor income respectively are relatively stable.

\section{Appendix B}

\section{Variables' plot}

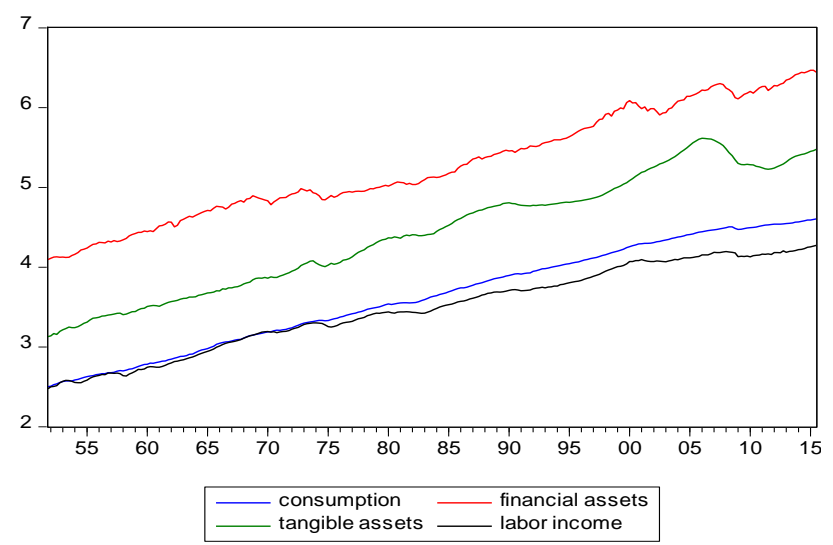

\section{Copyrights}

Copyright for this article is retained by the author(s), with first publication rights granted to the journal.

This is an open-access article distributed under the terms and conditions of the Creative Commons Attribution license (http://creativecommons.org/licenses/by/4.0/). 